\title{
Nutritional value of yellow-seeded winter rapeseed cakes for growing pigs
}

Ewa Święch ${ }^{1}$, Stanisława Raj ${ }^{1}$, Barbara Pastuszewska ${ }^{1}$, Marcin Taciak ${ }^{1}$, Iwona Bartkowiak-Broda², Stefania Smulikowska ${ }^{1}$

${ }^{1}$ The Kielanowski Institute of Animal Physiology and Nutrition Polish Academy of Sciences, 05-110 Jabłonna, Poland

${ }^{2}$ Oil Crop Department, Plant Breeding and Acclimatization Institute, Poznań, Poland

e-mail: e.swiech@ifzz.pl

\begin{abstract}
Objective of the study was to compare the composition and nutritional value of a winter brown- (BRC) and three yellow-seeded (YRC) cold-pressed rapeseed cakes as the components of pigs' diets, and to assess their effects on colonic bacterial fermentation and the relative weight of organs. In experiment 1, the standardised ileal digestibility (SID) of protein and amino acids (AA) of cakes was determined in 12 male cannulated pigs. Each diet was fed to six pigs during three seven-day periods. Ileal digesta was collected during the last three days of the period. In experiment 2, five groups each containing six female pigs with initial body weights (BW) of $20 \mathrm{~kg}$ were fed on diets containing BRC, YRC, or soyabean oil meal (SBM) as the main protein source. The apparent total tract digestibility (ATTD) of nutrients and growth performance were measured untill $60 \mathrm{~kg} \mathrm{BW}$ was reached, and short chain fatty acids (SCFA) concentrations in the colon, as well as the weight of the liver, kidney, heart, and thyroid, were recorded. The main differences between BRC and YRC were found in higher content of fat and protein, lower amounts of fibre and glucosinolates (GIs), and higher ATTD of fibre in YRC. Protein and AA SID, ATTD of nutrients, total SCFA colonic concentration, and growth performance did not significantly differ. The chemical composition of the three YRC was not uniform, the greatest differences were found among the amounts of Gls. The relative weights of the thyroid and heart were greater in pigs fed BRC than in YRC and SBM diets. Thyroid weight was positively correlated with dietary progoitrin, alkenyl Gls, and total Gls, whereas heart weight was positively correlated with progoitrin and alkenyl Gls. It was concluded that winter yellow-seeded rapeseed is a better raw material for cold-pressing than brown-seeded due to having lower Gls and fibre content.
\end{abstract}

Key words: yellow-seeded rapeseed, glucosinolates, digestibility, performance, organ weight, pigs

\section{Introduction}

The yellow-seeded double-low winter rapeseed line is developed and evaluated in Poland (Bartkowiak-Broda et al. 2011), whereas in Canada selection is directed towards the yellow-seeded spring rapeseed of the canola-variety. Composition of the brown- and yellow-seeded rapeseed is different. Yellow-seeded rapeseed has thinner hulls; contains less crude fibres, fibre fractions (particularly acid detergent fibre [ADF], neutral detergent fibre [NDF] and acid detergent lignin [ADL]), polyphenols, and glucosinolates (Gls); and more protein, oil, and sucrose than brown-seeded rapeseed (Simbaya et al. 1995, Smulikowska et al. 1998, Boros et al. 2011a, Slominski et al. 2012, Mejicanos et al. 2016). Oilseed meals and cakes produced from the yellow-seeded rapeseed have a higher nutritional value for broilers (Smulikowska et al. 1998, Slominski et al. 1999, Czerwinski et al. 2012) and rats (Smulikowska et al. 1998) than those made from brown-seeded rapeseed. However, data on the nutritional value of yellow-seeded winter rapeseed for pigs is lacking.

Different content and composition of fibre in brown- and yellow-seeded rapeseed may induce different microbial activities in the hind gut. Feeding meal from yellow-seeded rapeseed to turkeys led to significantly lower short chain fatty acids (SCFA) concentrations in caecal digesta than did feeding brown-seeded rapeseed meal (Zdunczyk et al. 2011), whereas feeding yellow-seeded rapeseed cakes (YRC) to chickens had inconsistent effects on this parameter (Czerwinski et al. 2012). Microbial fermentation affects gut health, total tract digestibility of nutrients, and nitrogen excretion patterns in monogastric animals. Microbial fermentation is more intensive in pigs than in poultry. Therefore, it is important not only to extend our knowledge on the nutritional value of YRC for pigs, but also to examine its effect on the activity of microflora in the large intestine.

Solvent extraction is the most commonly used method of oil separation from rapeseed. Pressing is used as an alternative industrial technology as it is considered as potentially more cost effective, pollution free, and safer than solvent extraction (Nyström et al. 1996). Small-scale oil factories producing press-cake are also currently being developed, and promoted as contributing to the sustainable agriculture. 
Rapeseed cake is a valuable high-energy feed, but it contains large amounts of residual Gls and induces greater enlargement of thyroid than solvent meal (Smulikowska et al. 1998). Yellow-seeded rapeseed may be considered a potentially safer raw material for cake production than brown-seeded rapeseed due to its lower contents of Gls.

The objective of the study was to assess both the nutritional value of YRC from three newly developed lines and to compare YRC with brown-seeded rapeseed cake (BRC) as the components of diets for young pigs. Assessment of the protein value of the rapeseed cakes comprised determination of their amino acid (AA) composition and standardised ileal digestibility (SID) of protein and AA. The apparent total tract digestibility (ATTD) of nutrients and fibre fractions were determined and the concentration of SCFA and $\mathrm{pH}$ of colon digesta were measured in pigs fed diets containing one of four different rapeseed cakes or soyabean oil meal (SBM). Growth performance and relative weights of organs, including the thyroid, were recorded.

\section{Material and methods}

\section{Rapeseed cakes}

Seeds of three lines of yellow-seeded 00 winter rapeseed $(41,36$, and 22 ) and one brown-seeded rapeseed cultivar (Bojan) were used. Yellow-seeded lines of rapeseeds have been developed via crosses of spontaneous mutant having lighter coloured seeds (found in breeding materials) with segregating, spotted-seed-coat spring line (from earlier crosses of rapeseed [Brassica napus] with turnip rape [Brassica rapa]). The obtained lines have been improved with respect to quality features and selected only with stable expression of yellow-seededness. Bojan is a commercially available winter rapeseed Polish cultivar, an open pollinated 00 type (canola-type). The lines, as well as the cultivar Bojan, were grown in the field trials at the Experimental Station Łagiewniki (Poland), belonging to the Plant Breeding Company Smolice (Poland), in seasons 2008/2009 and 2009/2010. The seeds were cold-pressed at a local factory with the use of a small capacity screw press (Farmet Duo, Farmet a.s., Ceska Skalice, Czech Republic). The temperature of the rapeseed cakes during pressing did not exceed $55^{\circ} \mathrm{C}$. The cakes were then expelled through a $10-\mathrm{mm}$ sieve plate as pellets and ground before use in the diets.

\section{Animals and experimental procedures}

All procedures were approved by the Third Local Animal Care Committee in Warsaw (Poland).

\section{Experiment 1}

Experiment 1 was performed on 12 male pigs (Polish Large White $\times$ Duroc, supplied by the Warsaw University of Life Sciences, Poland) having initial body weights (BW) of approximately $20 \mathrm{~kg}$. Animals were housed individually in metabolism cages equipped with feeders and nipple drinkers in a temperature-controlled room $\left(22-23^{\circ} \mathrm{C}\right)$. After a six-day adaptation to the environmental conditions, pigs were surgically fitted with a post-valvular T-caecum cannula (PVTC) in accordance with the method of van Leeuwen et al. (1991). The ten-day recovery was followed by three seven-day periods of feeding the experimental diets. During each seven-day period, each diet was fed to two or three animals to achieve a total number of six animals per diet. The rapeseed cake diets contained wheat and one of four different rapeseed cakes. The control diet contained maize starch instead of rapeseed cake (Table 1). All diets were free of antibiotics and growth promoters. Before the mixing of diets, the fat content of the rapeseed cakes was standardised by the addition of oil pressed from the rapeseed. Diets were supplemented with crystalline AA to cover the requirements for essential AA according to NRC (1998), and chromium oxide was added as a marker. Pigs were fed twice daily at 0800 and $2000 \mathrm{~h}$ with equal portions of diets mixed with water in a 1:1 ratio. Animals had free access to water. The feeding level was adjusted to 2.7 times the maintenance requirement (NRC 1998) for metabolisable energy (ME) corresponding to about $90 \%$ of ad libitum intake. Feed allowances were changed weekly according to BW. During the last three days of each period, ileal digesta was collected in plastic bags for $12 \mathrm{~h}$ per day from 0800 to $2000 \mathrm{~h}$ (between meals). The bags were connected to the cannulas and were changed at least every hour. Collected digesta was immediately frozen at $-20^{\circ} \mathrm{C}$. After completing the collections, the samples were thawed, and pooled per animal within each experimental period, freeze dried and ground $(0.5 \mathrm{~mm})$ before chemical analysis. The pigs were slaughtered at the end of the experiment after electrical stunning. After dissection, the pigs were examined to determine whether cannulation had caused any intestinal abnormalities. 
Table 1. Composition of diets used in Experiment 1

\begin{tabular}{|c|c|c|c|c|c|}
\hline & \multicolumn{5}{|c|}{ Diet } \\
\hline & YRC-41 & YRC-36 & YRC-22 & BRC & Control \\
\hline \multicolumn{6}{|l|}{ Ingredients, $\mathrm{g} \mathrm{kg}^{-1}$} \\
\hline wheat & 600.0 & 600.0 & 600.0 & 600.0 & 600.0 \\
\hline rapeseed cake ${ }^{*}$ & 300.0 & 300.0 & 300.0 & 300.0 & \\
\hline maize starch & 26.0 & 26.0 & 26.0 & 26.0 & 314.5 \\
\hline sugar & 50.0 & 50.0 & 50.0 & 50.0 & 50.0 \\
\hline limestone & 10.0 & 10.0 & 10.0 & 10.0 & 8.0 \\
\hline monocalcium phosphate & 1.0 & 1.0 & 1.0 & 1.0 & 14.0 \\
\hline $\mathrm{NaCl}$ & 2.5 & 2.5 & 2.5 & 2.5 & 3.0 \\
\hline premix $^{* *}$ & 5.0 & 5.0 & 5.0 & 5.0 & 5.0 \\
\hline L-lysine $\mathrm{HCl}(78 \%)$ & 2.2 & 2.2 & 2.2 & 2.2 & 2.2 \\
\hline L-threonine (98\%) & 0.3 & 0.3 & 0.3 & 0.3 & 0.3 \\
\hline chromium oxide & 3.0 & 3.0 & 3.0 & 3.0 & 3.0 \\
\hline \multicolumn{6}{|l|}{ Content $^{* * *}, \mathrm{~g} \mathrm{~kg}^{-1}$} \\
\hline DM & 907.4 & 904.6 & 905.7 & 899.4 & 889.6 \\
\hline crude protein & 178.8 & 175.5 & 180.0 & 182.5 & 91.9 \\
\hline crude fat & 97.1 & 102.1 & 100.6 & 74.4 & 10.7 \\
\hline crude fibre & 52.9 & 40.2 & 40.5 & 50.9 & 22.7 \\
\hline \multicolumn{6}{|l|}{ Glucosinolates ${ }^{* * * *}, \mu \mathrm{mol} \mathrm{g}^{-1}$} \\
\hline progoitrin & 0.15 & 0.36 & 0.42 & 1.17 & \\
\hline alkenyl glucosinolates & 0.66 & 0.99 & 1.11 & 2.13 & \\
\hline total glucosinolates & 2.37 & 2.76 & 2.79 & 3.38 & \\
\hline \multicolumn{6}{|c|}{$\begin{array}{l}\mathrm{YRC}=\text { yellow-seeded cake, } \mathrm{BRC}=\text { brown-seeded cake; } \mathrm{DM}=\text { dry matter; }{ }^{*} \text { rapeseed cakes were supplemented with oil pressed from th } \\
\text { respective rapeseed; "* premix provided per kg of diet: vitamin } A-15000 \mathrm{IU} \text {, vitamin } \mathrm{D}_{3}-2000 \mathrm{IU} \text {, vitamin } \mathrm{E}-60 \mathrm{mg} \text {, vitamin } \mathrm{K}-3 \mathrm{mg} \\
\text { vitamin } \mathrm{B}_{1}-1 \mathrm{mg} \text {, vitamin } \mathrm{B}_{2}-4 \mathrm{mg} \text {, vitamin } \mathrm{B}_{3}-20 \mathrm{mg} \text {, vitamin } \mathrm{B}_{5}-15 \mathrm{mg} \text {, vitamin } \mathrm{B}_{6}-3 \mathrm{mg} \text {, vitamin } \mathrm{B}_{7}-0.25 \mathrm{mg} \text {, vitamin } \mathrm{B}_{12}-0.0 \\
\mathrm{mg} \text {, folic acid }-5 \mathrm{mg} \text {, choline }-150 \mathrm{mg}, \mathrm{Mg}-150 \mathrm{mg}, \mathrm{Mn}-50 \mathrm{mg}, \mathrm{Zn}-150 \mathrm{mg}, \mathrm{Se}-0.3 \mathrm{mg}, \mathrm{Cu}-150 \mathrm{mg}, \mathrm{Fe}-125 \mathrm{mg}, \mathrm{Ca}-1.3 \mathrm{~g} \\
\text { "*analysed; }{ }^{* * *} \text { calculated }\end{array}$} \\
\hline
\end{tabular}

\section{Experiment 2}

Experiment 2 was performed on 30 female pigs ([Polish Large White $\times$ Danish Landrace] $\times$ Duroc, supplied by Agro-Sokłów, Jagodne, Poland) having initial BW of approximately $20 \mathrm{~kg}$. After seven-day of adaptation to the environmental conditions, the pigs were allocated to five groups (six pigs in each), taking BW, age, and litter into account. Animals were housed individually in pens with slatted floors equipped with feeders and nipple drinkers in a temperature-controlled room $\left(22-23^{\circ} \mathrm{C}\right)$. Pigs had free access to water. The control diet contained maize, wheat, barley, and SBM. The rapeseed cake diets contained one of the rapeseed cakes instead of the SBM portion of the control diet (Table 2). Diets were supplemented with crystalline AA (included in the premix) to cover the requirements for essential AA according to NRC (1998). The pigs were fed twice a day at 0800 and $1400 \mathrm{~h}$ with equal portions of the diets. Diets were provided in mash form. Pigs were fed at an $85 \%$ level of ad libitum intake and feed allowances were changed weekly according to BW. At approximately $45 \mathrm{~kg}$ BW, pigs were fed for eight days on diets with added chromium oxide $\left(2 \mathrm{~g} \mathrm{~kg}^{-1} \mathrm{diet}\right)$. After a four-day preliminary feeding period, freshly voided faeces were collected over four days at 0800 and $1500 \mathrm{~h}$ and were immediately frozen at $-20^{\circ} \mathrm{C}$. At the end of the collection period, faeces were thawed, mixed, and subsampled for analysis. Pigs were fed experimental diets for approximately 54 days until about $60 \mathrm{~kg}$ of BW, at which time they were slaughtered after electrical stunning. The liver, kidneys, heart, and thyroid were excised from each pig and weighed. Digesta from the proximal and middle sections of the colon were collected immediately after slaughter for dry matter (DM), pH, and SCFA determination. Digesta for $\mathrm{pH}$ and SCFA determination were mixed with ultra pure water in a 1:2 ratio. The $\mathrm{pH}$ of digesta samples was then measured and adjusted to 8.0 with $1 \mathrm{M} \mathrm{NaOH}$, afterwards the samples were centrifuged and the supernatants stored at $-20^{\circ} \mathrm{C}$ untill analyses. 


\section{Chemical analyses}

Dietary ingredients, diets, ileal digesta, and faeces were analysed for DM, nitrogen, crude fat, crude ash, crude fibre, starch, and sugars using standard methods (AOAC 2011, No. of procedures: 934.01, 984.13, 920.39, 942.05, 978.10, 920.40, and 974.06, respectively). The content of ADF, NDF, and ADL were determined in rapeseed cakes, diets, and faeces according to van Soest and Wine (1967) and van Soest (1973). Chromium content was determined in diets, ileal digesta, and faeces according to Kimura and Miller (1957). Amino acids except methionine, cysteine, and tryptophan were analysed in rapeseed cakes, diets, and ileal digesta with a Beckman high-pressure AA analyser (Beckman Instruments, Inc., Fulerton, CA, USA) using procedure No. 994.12 according to the AOAC (2011), except shorter hydrolysis (22 h) with $\mathrm{HCl}$. The gross energy of rapeseed cakes and diets was measured on a Parr adiabatic oxygen bomb KL-10 calorimeter (Precyzja, Bydgoszcz, Poland) according to the ISO 9831 method (ISO 2003). The contents of Gls in rapeseed cakes were determined according to the ISO 9167-1 method (ISO 1992) using a high-performance liquid chromatographer 1050 series apparatus (Hewlett Packard, San Fernando, CA). All measurements were performed in triplicates.

\begin{tabular}{|c|c|c|c|c|c|}
\hline & \multicolumn{4}{|c|}{ Diet $^{*}$} & \multirow[b]{2}{*}{ Control } \\
\hline & YRC-41 & YRC-36 & YRC-22 & $\mathrm{BRC}$ & \\
\hline \multicolumn{6}{|l|}{ Ingredients, $\mathrm{g} \mathrm{kg}^{-1}$} \\
\hline barley & 350 & 350 & 350 & 350 & 350 \\
\hline wheat & 200 & 200 & 200 & 190 & 220 \\
\hline maize & 134 & 145 & 144 & 139 & 159 \\
\hline rapeseed cake & 200 & 200 & 200 & 200 & \\
\hline soyabean oil meal & 80 & 80 & 80 & 80 & 200 \\
\hline rapeseed oil & 11 & & 1 & 16 & 46 \\
\hline premix $^{* *}$ & 25 & 25 & 25 & 25 & 25 \\
\hline \multicolumn{6}{|l|}{ Content $^{* * *}, \mathrm{~g} \mathrm{~kg}^{-1}$} \\
\hline DM & 876 & 874 & 877 & 880 & 872 \\
\hline crude protein & 174 & 174 & 179 & 182 & 182 \\
\hline crude fat & 78.9 & 77.1 & 76.4 & 89.5 & 45.3 \\
\hline crude fibre & 49.2 & 50.3 & 51.2 & 53.4 & 35.5 \\
\hline \multicolumn{6}{|l|}{ Glucosinolates $^{* * * *}, \mu \mathrm{mol} \mathrm{g}^{-1}$} \\
\hline progoitrin & 0.10 & 0.24 & 0.28 & 0.78 & \\
\hline alkenyl glucosinolates & 0.44 & 0.66 & 0.74 & 1.42 & \\
\hline total glucosinolates & 1.58 & 1.84 & 1.86 & 2.25 & \\
\hline
\end{tabular}

Digesta $\mathrm{pH}$ was measured with a WTW pH/340 pH-meter (WTW GmbH, Weilheim, Germany) and SCFA were analysed using a HP 5890 Series II gas chromatograph (Hewlett Packard, Waldbronn, Germany) with isocaproic acid as the internal standard as described by Barszcz et al. (2011).

\section{Calculations and statistical analysis}

The SID of protein and AA was estimated from AID of protein and AA of the diets calculated from the chromium content in the diets and ileal digesta using the following formula:

$$
\operatorname{AID}_{D}(\%)=100-\frac{\mathrm{Cr}_{D}(\%) \times C P / A A_{I D}(\%)}{C P / A A_{D}(\%) \times C r_{I D}(\%)} \times 100
$$

$A I D_{D}$ - apparent ileal digestibility of protein/AA in the diet

$\mathrm{Cr}_{\mathrm{D}}$ - chromium concentration in the diet

$\mathrm{Cr}_{\text {ID }}$ - chromium concentration in the ileal digesta

$C P / A A_{I D}$ - protein/AA concentration in the ileal digesta

$C P / A A_{D}$ - protein/AA concentration in the diet 
Additionally, the mean values of AID of protein and AA in the diets were further used for calculation of the AID of protein and AA of rapeseed cakes by the difference method using the following formula:

$$
\operatorname{AID}_{R C}(\%)=\frac{\operatorname{AID}_{R C D}(\%)-\operatorname{AID}_{W}(\%) \times C P / A A_{W}(\%)}{C P / A A_{R C}(\%)}
$$

$\mathrm{AID}_{\mathrm{RC}}$ - apparent ileal digestibility of protein/AA of rapeseed cake

$\mathrm{AID}_{\mathrm{RCD}}$ - apparent ileal digestibility of protein/AA of the rapeseed cake diet

$\mathrm{AID}_{\mathrm{W}}$ - apparent ileal digestibility of protein/AA of wheat

$C P / A A_{w}$ - contribution level of protein/AA in rapeseed cake diet originating from wheat

$C P / A A_{R C}$ - contribution level of protein/AA in rapeseed cake diet originating from rapeseed cake

The SID of protein and AA were estimated from the AID of protein and AA using tabulated values of basal endogenous AA losses (Jansman et al., 2002) according to the following formula:

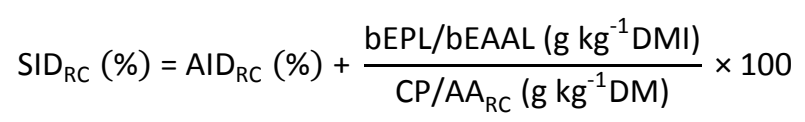

$\mathrm{SID}_{\mathrm{RC}}$ - standardized ileal digestibility of protein/AA in rapeseed cake

$A_{I D C}$ - apparent ileal digestibility of protein in rapeseed cake

bEPL/bEAAL - basal endogenous protein/AA losses

$\mathrm{CP} / \mathrm{AA}_{\mathrm{RC}}$ - content of $\mathrm{CP} / \mathrm{AA}$ in rapeseed cake

The calculation of ATTD of nutrients and fibre fractions in the diets was based on the chromium content in diets and faeces using the following formula:

$$
\operatorname{ATTD}_{D}(\%)=100-\frac{\mathrm{Cr}_{\mathrm{D}}(\%) \times \mathrm{N}_{F}(\%)}{\mathrm{N}_{\mathrm{D}}(\%) \times \mathrm{Cr}_{\mathrm{F}}(\%)} \times 100
$$

$A T T D_{D}$ - apparent total tract digestibility of nutrients/fibre fractions in the diet

$\mathrm{Cr}_{\mathrm{D}}$ - chromium concentration in the diet

$\mathrm{Cr}_{\mathrm{F}}$ - chromium concentration in the faeces

$\mathrm{N}_{\mathrm{D}}$ - nutrient/fibre fractions concentration in the diet

$\mathrm{N}_{\mathrm{F}}$ - nutrient/fibre fractions concentration in the faeces

The ME of diets was calculated based on the content of digestible nutrients using the following formula according to GfE (2008):

$\mathrm{ME}\left(\mathrm{MJ} \mathrm{kg}{ }^{-1} \mathrm{DM}\right)=0.0205 \times \mathrm{dP}\left(\mathrm{g} \mathrm{kg}^{-1} \mathrm{DM}\right)+0.0398 \mathrm{dF}\left(\mathrm{g} \mathrm{kg}^{-1} \mathrm{DM}\right)+0.0173 \times \mathrm{St}\left(\mathrm{g} \mathrm{kg}^{-1} \mathrm{DM}\right)+0.0160 \times \mathrm{Su}\left(\mathrm{g} \mathrm{kg}^{-1}\right.$ $\mathrm{DM})+0.0147 \times(\mathrm{dOM}-\mathrm{dP}-\mathrm{dF}-\mathrm{St}-\mathrm{Su})\left(\mathrm{g} \mathrm{kg}^{-1} \mathrm{DM}\right)$

dOM - digestible organic matter

$\mathrm{dP}$ - digestible protein

$\mathrm{dF}$ - digestible fat

St - starch

Su - sugar

The results were subjected to one-way analysis of variance (ANOVA) using the GLM procedure of STATISTICA 10 software (StatSoft 2011). Differences among rapeseed cakes in terms of SID of protein and AA were evaluated using contrasts: BRC vs. YRC, YRC-41 vs. YRC-36, YRC-41 vs. YRC-22, and YRC-36 vs. YRC-22. For results of Experiment 2, contrasts were additionally evaluated for control vs. BRC and control vs. YRC. The effects of animal and period were included into the statistical analysis of results of Experiment 1. Pearson's correlation coefficients of linear regression were calculated between the content of Gls (progoitrin, alkenyl Gls, and total Gls) in the diets and the relative weights of the heart and thyroid. The results were expressed as the mean of six pigs. Differences were considered significant at $p \leq 0.05$. 


\section{Results \\ Composition of the rapeseed cakes}

The chemical composition of YRC and BRC are shown in Table 3. YRC contained less crude protein, crude fibre, and fibre fractions, whereas it contained more crude fat and GE than BRC. The composition of the three YRC lines was not uniform, but differences among the cakes were small.

Amino acid composition of the three YRC lines and BRC protein was similar except for higher lysine content in BRC than in YRC (Table 3). Among the YRC lines, the YRC-41 contained slightly less several AA than the others.

The amounts of progoitrin, alkenyl, and total Gls were greater in BRC than in YRC (Table 3). The greatest difference both found between YRC and BRC and within the three YRC lines was for progoitrin, which was the lowest in YRC- 41 .

Table 3. Composition of yellow- and brown-seeded rapeseed cakes

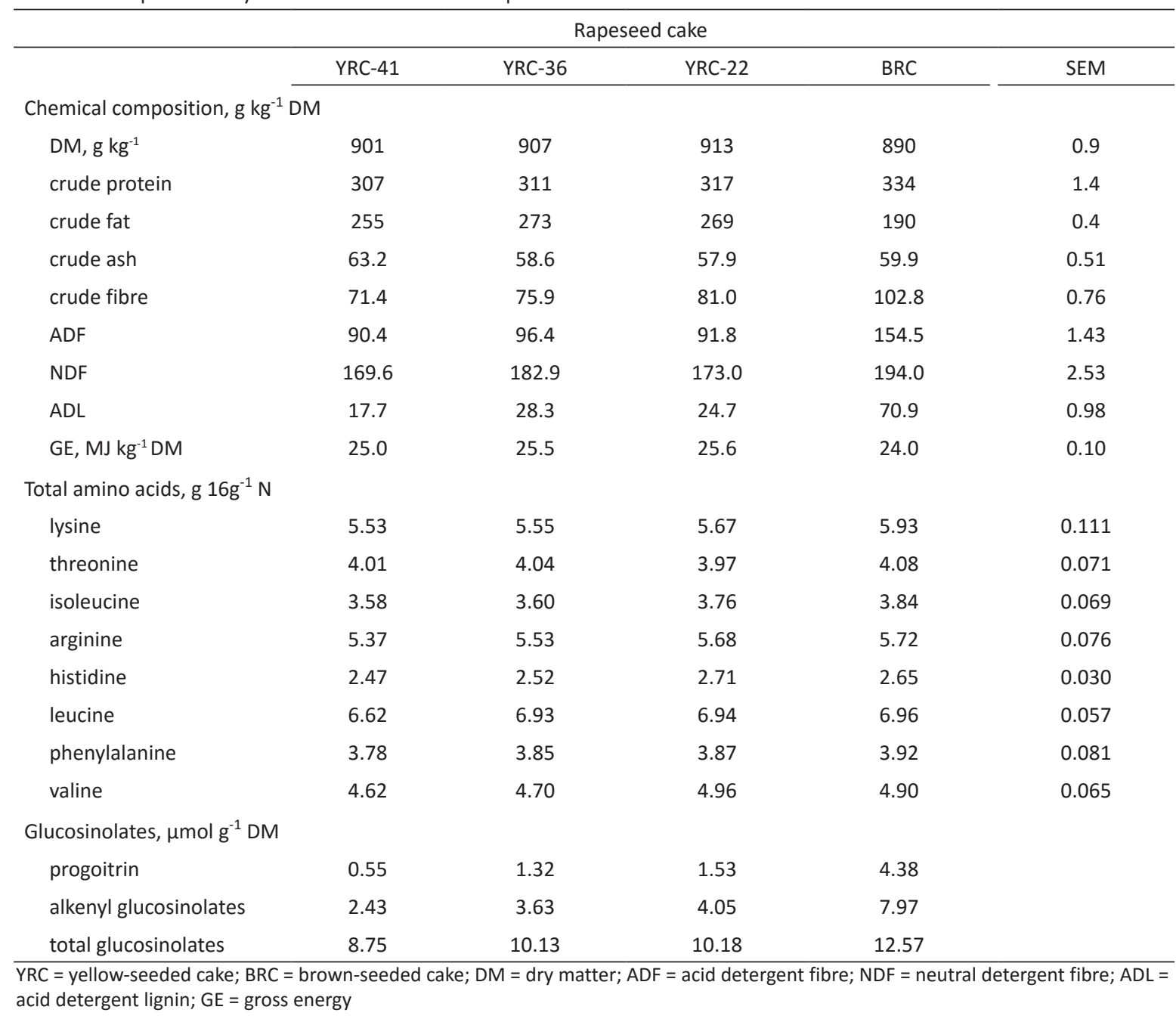

\section{lleal digestibility of protein and AA of the rapeseed cakes (Experiment 1)}

The SID of protein and all analysed AA did not differ between BRC and the three YRC lines (Table 4), whereas significant differences among the YRC lines were found for protein and several AA. 
E. Święch et al. (2016) 25: 99-110

Table 4. Standardised ileal digestibility of protein and amino acid (\%) in rapeseed cakes (Experiment 1)

\begin{tabular}{|c|c|c|c|c|c|c|c|c|c|}
\hline & \multicolumn{4}{|c|}{ Rapeseed cake } & & \multicolumn{4}{|c|}{ Contrast ( $p$-value) } \\
\hline & YRC-41 & YRC-36 & YRC-22 & BRC & SEM & YRC vs $B R C$ & $\begin{array}{l}\text { YRC-41 vs } \\
\text { YRC-36 }\end{array}$ & $\begin{array}{l}\text { YRC-41 vs } \\
\text { YRC-22 }\end{array}$ & $\begin{array}{l}\text { YRC-36 vs } \\
\text { YRC-22 }\end{array}$ \\
\hline Protein & 73.1 & 74.9 & 76.0 & 73.0 & 0.99 & 0.175 & 0.166 & 0.036 & 0.377 \\
\hline Lysine & 80.1 & 82.0 & 85.4 & 80.3 & 1.15 & 0.087 & 0.304 & 0.004 & 0.028 \\
\hline Threonine & 77.9 & 78.4 & 75.8 & 75.9 & 1.19 & 0.359 & 0.592 & 0.230 & 0.082 \\
\hline Isoleucine & 67.5 & 71.7 & 72.9 & 69.3 & 1.02 & 0.262 & 0.004 & 0.001 & 0.371 \\
\hline Arginine & 83.7 & 84.5 & 88.1 & 83.2 & 1.71 & 0.223 & 0.819 & 0.099 & 0.132 \\
\hline Histidine & 87.6 & 89.7 & 91.2 & 89.4 & 1.27 & 0.974 & 0.281 & 0.076 & 0.414 \\
\hline Leucine & 69.5 & 74.7 & 75.1 & 72.6 & 1.08 & 0.902 & 0.001 & 0.001 & 0.797 \\
\hline Phenylalanine & 67.7 & 74.4 & 77.6 & 73.0 & 1.26 & 0.913 & 0.001 & 0.001 & 0.031 \\
\hline Valine & 70.7 & 73.3 & 73.7 & 72.4 & 1.10 & 0.948 & 0.080 & 0.053 & 0.780 \\
\hline
\end{tabular}

YRC = yellow-seeded cake; BRC $=$ brown-seeded cake

The SID of protein was lower in the YRC-41 than in YRC-22 ( $p \leq 0.05)$. The SID of isoleucine and leucine were lower in the YRC-41 than in YRC-36 and YRC-22 ( $p \leq 0.01)$, while the SID of lysine was higher $(p \leq 0.05)$ in YRC-22 than in YRC-36 and YRC-41. The SID of Phe differed $(p \leq 0.05)$ among three YRC lines. In general, the SID of almost all AA was lowest in YRC-41 and the highest in YRC-22.

Apparent total tract digestibility of nutrients and energy value of diets containing rapeseed cakes or soyabean oil meal (Experiment 2)

The ATTD of protein and starch did not differ between rapeseed cake and control diets or among diets containing different cakes (Table 5). Differences between YRC and BRC diets was only found for the ATTD of fibre and fibre fractions, since ATTD of crude fibre and fibre fractions were higher $(p \leq 0.01)$ in YRC than in BRC diet. The ATTD of ash and NDF were lower $(p \leq 0.05)$ in the YRC-41 diet than in the YRC-36 diet and than in the other two YRC diets, respectively. The ATTD of fat was lower $(p \leq 0.05)$ in YRC-22, whereas ATTD of ADL was lower $(p \leq 0.05)$ in YRC-36 than in the other two YRC diets. The ATTD of organic matter and ash was lower $(p \leq 0.01)$ in all rapeseed cake diets than in the control diet. The ATTD of fibre, ADF, and NDF were lower $(p \leq 0.01)$ in the YRC diets than in the control diet, whereas ATTD of ADL was lower $(p \leq 0.01)$ in the BRC than in the control diet. In general, the inclusion of both YRC and BRC into the control diet depressed ATTD of organic matter and ash, BRC additionally depressed ATTD of ADL, whereas YRC decreased ATTD of fibre, ADF, and NDF.

Table 5. Apparent total tract digestibility of nutrients and fibre fractions (\%) and metabolisable energy content (ME, MJ kg ${ }^{-1}$ ) in diets containing rapeseed cake or the control diet containing soyabean oil meal (Experiment 2)

\begin{tabular}{|c|c|c|c|c|c|c|c|c|c|c|c|c|}
\hline & \multicolumn{6}{|c|}{ Diet } & \multicolumn{6}{|c|}{ Contrast ( $p$-value) } \\
\hline & YRC-41 & YRC-36 & YRC-22 & $\mathrm{BRC}$ & Control & SEM & $\begin{array}{c}\text { YRC } \\
v s \\
\text { BRC }\end{array}$ & $\begin{array}{c}\text { YRC-41 } \\
\text { vs } \\
\text { YRC-36 }\end{array}$ & $\begin{array}{c}\text { YRC-41 } \\
\text { vs } \\
\text { YRC-22 }\end{array}$ & $\begin{array}{c}\text { YRC-36 } \\
\text { vs } \\
\text { YRC-22 }\end{array}$ & $\begin{array}{c}\text { Control } \\
\text { vs } \\
\text { YRC }\end{array}$ & $\begin{array}{c}\text { Control } \\
\text { vs } \\
\text { BRC }\end{array}$ \\
\hline \multicolumn{13}{|c|}{ Apparent total tract digestibility, \% } \\
\hline organic matter & 84.8 & 85.4 & 84.2 & 84.7 & 86.4 & 0.35 & 0.711 & 0.186 & 0.237 & 0.022 & 0.003 & 0.005 \\
\hline protein & 77.4 & 79.3 & 77.5 & 78.8 & 78.6 & 1.00 & 0.515 & 0.204 & 0.957 & 0.222 & 0.667 & 0.895 \\
\hline fat & 64.6 & 67.9 & 60.1 & 65.5 & 63.7 & 1.24 & 0.385 & 0.075 & 0.019 & 0.001 & 0.714 & 0.337 \\
\hline ash & 43.0 & 46.0 & 44.3 & 45.3 & 50.6 & 0.76 & 0.347 & 0.012 & 0.210 & 0.141 & 0.001 & 0.001 \\
\hline starch & 97.9 & 98.1 & 98.0 & 98.1 & 98.2 & 0.17 & 0.550 & 0.601 & 0.833 & 0.753 & 0.384 & 0.770 \\
\hline fibre & 54.3 & 52.7 & 56.3 & 46.7 & 43.0 & 1.94 & 0.003 & 0.546 & 0.467 & 0.194 & 0.001 & 0.219 \\
\hline$A D F$ & 57.9 & 58.4 & 60.0 & 45.9 & 50.0 & 1.53 & 0.001 & 0.832 & 0.331 & 0.442 & 0.001 & 0.095 \\
\hline NDF & 66.9 & 71.3 & 71.9 & 54.9 & 58.5 & 1.31 & 0.001 & 0.030 & 0.015 & 0.734 & 0.001 & 0.087 \\
\hline ADL & 41.9 & 30.4 & 49.3 & 24.0 & 41.2 & 3.26 & 0.001 & 0.023 & 0.120 & 0.001 & 0.867 & 0.003 \\
\hline $\mathrm{ME}, \mathrm{MJ} \mathrm{kg}^{-1}$ & 13.9 & 14.1 & 13.8 & 14.2 & 13.6 & 0.07 & 0.001 & 0.072 & 0.399 & 0.014 & 0.009 & 0.001 \\
\hline
\end{tabular}

YRC = yellow-seeded cake; $B R C$ = brown-seeded cake; $A D F=$ acid detergent fibre; NDF = neutral detergent fibre; $A D L=$ acid detergent lignin; $\mathrm{ME}=$ metabolisable energy 
Short-chain fatty acid content in colonic digesta (Experiment 2)

The $\mathrm{pH}$ and concentrations of SCFA in the digesta from the proximal and middle sections of the colon were not affected by the diet except for higher $(p \leq 0.05)$ concentrations of propionate in the digesta of the proximal colon of pigs fed the BRC diet compared to the YRC diets (Table 6). The content of DM was lower $(p \leq 0.05)$ in the digesta from the proximal colon of pigs fed the YRC-41 than the YRC-36 diet, and in the middle colon digesta of pigs fed the control diet compared to the YRC and BRC diets. Total SCFA concentration was greater and $\mathrm{pH}$ was lower in the proximal than in the middle colon. In both colon sections, the main SCFA were acetate $(53-57 \%$ of total SCFA), propionate ( $25-29 \%$ of total SCFA), and butyrate (14-17\% of total SCFA).

Table 6. Short-chain fatty acids concentration $\left(\mu \mathrm{mol} \mathrm{g}^{-1}\right), \mathrm{pH}$, and dry matter content $\left(\mathrm{g} \mathrm{kg}^{-1}\right)$ of colon digesta of pigs fed diets containing rapeseed cake or the control diet containing soyabean oil meal (Experiment 2)

\begin{tabular}{|c|c|c|c|c|c|c|c|c|c|c|c|c|}
\hline & \multicolumn{6}{|c|}{ Diet } & \multicolumn{6}{|c|}{ Contrast ( $p$-value) } \\
\hline & YRC-41 & YRC-36 & YRC-22 & BRC & Control & SEM & $\begin{array}{c}\text { YRC } \\
v s \\
\text { BRC }\end{array}$ & $\begin{array}{c}\text { YRC-41 } \\
\text { vs } \\
\text { YRC-36 }\end{array}$ & $\begin{array}{c}\text { YRC-41 } \\
\text { vs } \\
\text { YRC-22 }\end{array}$ & $\begin{array}{c}\text { YRC-36 } \\
\text { vs } \\
\text { YRC-22 }\end{array}$ & $\begin{array}{c}\text { Control } \\
\text { vs } \\
\text { YRC }\end{array}$ & $\begin{array}{c}\text { Control } \\
\text { vs } \\
\text { BRC }\end{array}$ \\
\hline \multicolumn{13}{|l|}{ Proximal colon } \\
\hline \multicolumn{13}{|c|}{ Concentration, $\mu \mathrm{mol} \mathrm{g}{ }^{-1}$} \\
\hline acetate & 62.34 & 53.52 & 62.86 & 65.19 & 66.10 & 4.184 & 0.236 & 0.147 & 0.927 & 0.126 & 0.239 & 0.886 \\
\hline propionate & 31.08 & 28.14 & 29.38 & 35.00 & 33.90 & 2.096 & 0.027 & 0.329 & 0.552 & 0.677 & 0.120 & 0.730 \\
\hline butyrate & 16.60 & 16.38 & 16.70 & 18.56 & 16.80 & 1.457 & 0.226 & 0.915 & 0.959 & 0.877 & 0.901 & 0.428 \\
\hline valerate & 1.91 & 2.10 & 1.90 & 2.33 & 2.24 & 0.189 & 0.096 & 0.432 & 0.959 & 0.465 & 0.274 & 0.756 \\
\hline total SCFA & 114.5 & 103.3 & 113.6 & 123.9 & 122.1 & 6.49 & 0.072 & 0.232 & 0.921 & 0.269 & 0.179 & 0.847 \\
\hline $\mathrm{pH}$ & 6.50 & 6.66 & 6.70 & 6.52 & 6.58 & 0.057 & 0.415 & 0.436 & 0.074 & 0.331 & 0.865 & 0.451 \\
\hline $\mathrm{DM}, \mathrm{g} \mathrm{kg}^{-1}$ & 149.3 & 177.4 & 165.8 & 172.2 & 157.0 & 7.27 & 0.332 & 0.012 & 0.104 & 0.268 & 0.449 & 0.177 \\
\hline \multicolumn{13}{|l|}{ Middle colon } \\
\hline \multicolumn{13}{|c|}{ Concentration, $\mu \mathrm{mol} \mathrm{g}{ }^{-1}$} \\
\hline acetate & 45.87 & 49.19 & 47.86 & 48.58 & 48.07 & 4.466 & 0.850 & 0.602 & 0.742 & 0.834 & 0.941 & 0.940 \\
\hline propionate & 20.81 & 23.19 & 21.88 & 22.52 & 21.91 & 2.191 & 0.819 & 0.447 & 0.719 & 0.673 & 0.985 & 0.854 \\
\hline butyrate & 14.22 & 15.27 & 14.23 & 14.92 & 14.50 & 1.251 & 0.804 & 0.555 & 0.996 & 0.559 & 0.968 & 0.828 \\
\hline valerate & 1.97 & 2.35 & 2.24 & 2.65 & 2.26 & 0.236 & 0.092 & 0.270 & 0.396 & 0.763 & 0.808 & 0.290 \\
\hline total SCFA & 87.5 & 94.7 & 91.6 & 94.4 & 92.2 & 8.27 & 0.729 & 0.536 & 0.715 & 0.785 & 0.927 & 0.860 \\
\hline $\mathrm{pH}$ & 6.74 & 6.93 & 6.90 & 7.00 & 6.98 & 0.084 & 0.141 & 0.128 & 0.190 & 0.771 & 0.286 & 0.856 \\
\hline $\mathrm{DM}, \mathrm{g} \mathrm{kg}^{-1}$ & 228.5 & 228.3 & 235.7 & 232.5 & 215.9 & 4.31 & 0.731 & 0.983 & 0.221 & 0.235 & 0.014 & 0.018 \\
\hline
\end{tabular}

YRC = yellow-seeded cake; BRC = brown-seeded cake; SCFA = short chain fatty acids; DM = dry matter

Growth performance and organ weight (Experiment 2)

Neither of the growth performance parameters were affected by the diet (Table 7). In addition, the relative liver weight did not differ between the control and rapeseed cake or among the rapeseed cakes diets.

Table 7. Performance parameters and organ weights in pigs fed diets containing rapeseed cake or the control diet containing soyabean oil meal (Experiment 2)

\begin{tabular}{|c|c|c|c|c|c|c|c|c|c|c|c|c|}
\hline \multirow[b]{2}{*}{$\begin{array}{l}\text { Growth } \\
\text { performance }\end{array}$} & \multicolumn{6}{|c|}{ Diet } & \multicolumn{6}{|c|}{ Contrast ( $p$-value) } \\
\hline & YRC-41 & YRC-36 & YRC-22 & BRC & Control & SEM & $\begin{array}{c}\text { YRC } \\
v s \\
\text { BRC }\end{array}$ & $\begin{array}{c}\text { YRC-41 } \\
\text { vs } \\
\text { YRC-36 }\end{array}$ & $\begin{array}{c}\text { YRC-41 } \\
\text { vs } \\
\text { YRC-22 }\end{array}$ & $\begin{array}{c}\text { YRC-36 } \\
\text { vs } \\
\text { YRC-22 }\end{array}$ & $\begin{array}{c}\text { Control } \\
\text { vs } \\
\text { YRC }\end{array}$ & $\begin{array}{c}\text { Control } \\
\text { vs } \\
\text { BRC }\end{array}$ \\
\hline initial BW, kg & 20.3 & 20.3 & 20.2 & 20.4 & 20.0 & 0.13 & 0.363 & 0.917 & 0.467 & 0.426 & 0.145 & 0.060 \\
\hline final BW, kg & 61.5 & 59.8 & 58.9 & 60.7 & 56.9 & 1.28 & 0.625 & 0.346 & 0.139 & 0.623 & 0.069 & 0.057 \\
\hline ADG, $\mathrm{g} \mathrm{day}^{-1}$ & 725 & 756 & 719 & 716 & 734 & 23.4 & 0.520 & 0.352 & 0.845 & 0.267 & 0.985 & 0.623 \\
\hline $\mathrm{FCR}, \mathrm{kg}_{\mathrm{fi}} \mathrm{kg}^{-1}$ & 2.68 & 2.50 & 2.67 & 2.72 & 2.56 & 0.107 & 0.378 & 0.255 & 0.927 & 0.291 & 0.708 & 0.333 \\
\hline \multicolumn{13}{|c|}{ Organ weight, $\mathrm{g} \mathrm{kg}^{-1} \mathrm{BW}$} \\
\hline liver & 23.2 & 23.4 & 23.0 & 25.0 & 22.1 & 0.10 & 0.126 & 0.912 & 0.842 & 0.764 & 0.428 & 0.075 \\
\hline kidneys & 5.3 & 4.7 & 5.3 & 5.0 & 4.7 & 0.02 & 0.577 & 0.055 & 0.888 & 0.042 & 0.157 & 0.407 \\
\hline heart & 5.1 & 4.9 & 5.3 & 5.7 & 4.9 & 0.02 & 0.021 & 0.575 & 0.489 & 0.228 & 0.537 & 0.027 \\
\hline $\begin{array}{l}\text { thyroids, } \mathrm{mg} \\
100 \mathrm{~g}^{-1} \mathrm{BW}\end{array}$ & 10.25 & 9.65 & 10.19 & 12.29 & 7.81 & 0.878 & 0.029 & 0.635 & 0.962 & 0.667 & 0.062 & 0.003 \\
\hline
\end{tabular}

$\overline{\mathrm{YRC}}=$ yellow-seeded cake; $\mathrm{BRC}=$ brown-seeded cake; $\mathrm{ADG}=$ average daily gain; $\mathrm{FCR}=$ feed conversion ratio; $\mathrm{kg}_{\mathrm{fi}}=\mathrm{kg}_{\mathrm{g}}$ of feed intake; $\mathrm{kg}_{\mathrm{g}}=\mathrm{kg}$ of daily gain; Means in row with different superscripts differ at $p \leq 0.05(a, b)$ 
The relative weights of the thyroid and heart were significantly greater $(p \leq 0.01)$ in pigs fed a BRC diet in comparison with the YRC and control diets. The relative weight of the kidney was lower $(p \leq 0.05)$ in the pigs fed the YRC-36 than the YRC-22 diet.

The relative weight of the thyroid was positively correlated with dietary progoitrin, alkenyl Gls, and total Gls contents $(p \leq 0.01)$, whereas heart weight was positively correlated with progoitrin and alkenyl Gls $(p \leq 0.01$ and $p \leq$ 0.05 , respectively) (Table 8 ).

Table 8. Relationship between the content of glucosinolates in diets $\left(\mu \mathrm{mol} \mathrm{g}{ }^{-1}\right.$ ) and the relative weight of thyroid and heart $\left(\mathrm{g} \mathrm{kg}^{-1}\right.$ BW) in pigs fed diets containing rapeseed cake or the control diet containing soyabean oil meal $($ Experiment $2, \mathrm{n}=30)$

\begin{tabular}{|c|c|c|c|}
\hline Organ weight, $\mathrm{g} \mathrm{kg}^{-1} \mathrm{BW}$ & Glucosinolates content, $\mu \mathrm{mol} \mathrm{g}^{-1}$ & r & $p$ \\
\hline thyroid & progoitrin & 0.534 & 0.004 \\
\hline thyroid & alkenyl glucosinolates & 0.565 & 0.002 \\
\hline thyroid & total glucosinolates & 0.521 & 0.005 \\
\hline heart & progoitrin & 0.494 & 0.009 \\
\hline heart & alkenyl glucosinolates & 0.481 & 0.011 \\
\hline heart & total glucosinolates & 0.341 & 0.082 \\
\hline
\end{tabular}

$r=$ correlation coefficient

\section{Discussion}

The main differences between the composition of yellow and brown seeds of Brassica genotypes are a thinner and more translucent seed coat, higher oil and protein, and lower fibre contents, in the yellow seeds. Yellow-seeded rapeseed also contains less proanthocyanidins and tannins that cause lower digestibility of nutrients (Rahman and McVetty 2011). The potentially higher nutritional value of oil meal or cake made from yellow-seeded rapeseed is therefore hypothesised, but has not been unequivocally confirmed (Smulikowska et al. 1998, Boros et al. 2011b, Czerwinski et al. 2012, Khajali and Slominski 2012). The results of the present study on the composition of cakes from winter yellow- and brown-seeded rapeseeds are in agreement with findings of other authors comparing different botanical forms of rapeseed (Rahman and McVetty 2011) and winter rapeseed lines (Boros et al. 2011a). These authors reported that in yellow seeds the content of lignin is lower, whereas in meals prepared from these seeds the contents of protein and fat is higher than in meals made from brown seeds. The higher fat content found in YRC than in BRC in the present study might be the consequence of poorer efficiency of pressing oil from yellow seeds with lower lignin content, which distorts to some extent the inherent differences between the two rapeseed types. When chemical composition of the cakes is recalculated on a fat-free DM basis, the content of crude fibre, ADF, and ADL are still considerably lower in YRC than in BRC, whereas content of NDF is similar.

High fibre content in rapeseed oil meal is an important factor reducing energy and protein utilisation in monogastric animals (Khajali and Slominski 2012, Mejicanos et al. 2016). Since the yellow-seeded rapeseeds contain less fibre than the brown varieties, a higher nutritional value of YRC than of BRC was assumed. However, contrary to this expectation, the SID of protein and AA found in our study did not differ between the two types of cakes. This result contrasts with that of Slominski et al. (2011), who found that the ileal digestibility of total and several AA in broilers was higher in yellow than in brown-seeded canola. Moreover, in our recent study, small but significant differences of protein and AA SID values were found among the three different YRC lines. In this group, the lowest SID values of protein and all analysed AA were recorded in YRC-41, which also had the lowest amounts of crude fibre and fibre fractions. These results show that the general assumption of a negative relationship between fibre content and protein digestibility of rapeseed oil meal may not be valid in the case of cold-pressed rapeseed cakes and may indicate that some other minor components not analysed in our study, and not directly related to the seed colour, are involved.

The SID values of lysine, threonine, and several other essential AA in all rapeseed cakes were higher than the respective values for rapeseed meals published in INRA Tables (Sauvant et al. 2004). The superiority of cake digestibility can be explained by the absence of heat treatment, which leads to an increase in protein bound to NDF and negatively affects the ileal digestibility of protein and AA in canola and rapeseed meals (Buraczewska 2001). The SID values of lysine, threonine, and histidine of all winter rapeseed cakes under study were higher, whereas those of protein, isoleucine, and phenylalanine lower than respective mean values of canola expeller meal according to NRC (2012). 
In the present study, ATTD of protein did not differ between diets containing rapeseed cakes and the control diet containing SBM, or among rapeseed cake diets themselves. Similar results were reported by Smulikowska et al. (1998), who found that the total tract digestibility of protein in rapeseed cakes for rats was not affected by the type of rapeseed used, whereas in heat-treated meals it was higher in yellow than brown rapeseed meal. Moreover, in chicken, the protein digestibility of the same BRC and YRC as those used in our study did not differ (Czerwinski et al. 2012).

The only significant and considerable differences between ATTD of diets containing BRC and YRC concerned crude fibre and all analysed fibre fractions. The ATTD values of these components in BRC diets were lower than those in all YRC diets, but significant differences were also found within the three YRC diets. The relative differences were the greatest for ADL, which was the least digested in both the BRC and YRC-36 diets. Since digestion of fibre takes place in the large intestine due to the activity of microflora and is affected by physical characteristics and composition of fibre, the differences in the production of SCFA as the end-products of microbial fermentation in the colon could be expected. However, measurements of the SCFA concentration in colonic digesta did not fully confirm this assumption, since only propionate concentration was higher in the pigs fed on BRC diets in comparison to YRC diets, but only in the proximal colon. The apparent discrepancy between different ATTDs (as the final effect of fibre digestion) and uniform colonic concentration of SCFAs (as its metabolites) may be explained by different rates of fibre fractions fermentation and absorption of fatty acids, which were not determined in our study. Our results in pigs are partly conform to the results of Czerwinski et al. (2012), who evaluated the same rapeseed cakes in chickens and in one experiment found higher caecal propionate concentration in birds fed the BRC than the YRC diets. The effect of rapeseed on SCFA found in chickens in two different experiments were, however, inconsistent.

The content of Gls is an important parameter of the nutritional value of rapeseed products, since their degradation products have many adverse effects on growth performance, mainly due to impairment of thyroid and liver functions (Campbell and Schöne 1998, Tripathi and Mishra 2007, Schöne et al. 2011). The dietary levels of Gls are commonly expressed as their total concentration, but according to Campbell and Schöne (1998) the compound responsible for major antinutritive effects of rapeseed is progoitrin. In the present study, the differences in progoitrin concentration between BRC and YRC and among YRC lines were greater than for total Gls; concentration was particularly low in YRC-41. It may therefore be concluded that the yellow-seeded rapeseed is a better raw material for the cold-pressing of cake than the brown variety, but that variability among different lines should be taken into account. The highest total Gls content of $12.57 \mu \mathrm{mol} \mathrm{g}^{-1} \mathrm{DM}$ found in BRC was lower than the mean concentration of $19.0 \mu \mathrm{mol} \mathrm{g}^{-1} \mathrm{DM}$ found in 23 rapeseed cakes sampled in 10 oil mills in France (Schöne et al. 2011). In our study, the concentration of total Gls in diets containing $200 \mathrm{~g}$ of rapeseed cake per kg varied from $1.58 \mu \mathrm{mol} \mathrm{g}^{-1} \mathrm{DM}$ in YRC-41 diet to $2.25 \mu \mathrm{mol}$ in BRC diet, the latter value being slightly higher than the $2 \mu_{\mathrm{mol} \mathrm{g}}^{-1} \mathrm{DM}$ considered as the safe upper limit for growing pigs (Tripathi and Mishra 2007). All rapeseed cake diets were well accepted by pigs and did not induce deterioration of growth performance or hypertrophy of the liver, with the relative weights of thyroids only being greater in animals fed the BRC than the control diet. Different results were obtained in chickens fed diets containing the same rapeseed cakes, but at higher dietary levels (varying between 276 and $304 \mathrm{~g} \mathrm{~kg}^{-1}$ ). In the study, the relative thyroid weights were almost twice greater in birds fed the BRC diet than all the YRC diets, whereas relative liver weights were greater in BRC than in YRC-41 chickens (Czerwinski et al. 2012).

The apparent absence of deleterious effects of Gls in pigs can also be explained by the relatively short duration of the experiment, which comprised growth from 20 to $60 \mathrm{~kg}$ of BW. Nevertheless, in spite of the lack of significant treatment differences of organ weights, significant correlations between Gls (progoitrin, alkenyl Gls, and total Gls) contents and thyroid weights and between alkenyl Gls and progoitrin concentrations and relative heart weights, were found. Whereas the relationship of thyroid weight with dietary Gls content is in agreement with the welldocumented effects of Gls on this organ (Tripathi and Mishra 2007), the potential effect of Gls on heart weight has not been widely reported. The changes in organ weight are commonly considered an indication of modification of their functions (Rubio et al. 1999), therefore the physiological explanation and consequences of this relationship deserve further study.

\section{Conclusion}

The main advantage of cake produced from winter yellow- rather than brown-seeded rapeseed is its lower content of crude fibre, fibre fractions, and glucosinolates, particularly progoitrin. Yellow-seeded cold-pressed rapeseed cake can therefore be considered a better feed component, but the variability in the composition of the three yellow cakes under study indicates a lack of uniformity of the selected lines. The nutritional value of yellow-seeded rapeseed cake for pigs in terms of ileal digestibility of protein and amino acids, and growth performance is not 
higher than that of brown cake; the most evident difference is the better digestibility of fibre and fibre fractions in the whole digestive tract for diets containing yellow-seeded rapeseed cakes. The relative weights of the thyroid and heart, but not the liver, appear to be positively correlated with the dietary content of progoitrin and alkenyl glucosinolates.

\section{Acknowledgements}

This work was supported by Polish National Centre for Research and Development, Project No. N R12 04703. Part of the results were presented at 13th International Rapeseed Congress, 5-9 June 2011. Prague, Czech Republic.

\section{References}

AOAC 2011. Official Methods of Analysis. Association of Official Analytical Chemists. 18th ed, Galthersburg, MA. 2590 p.

Bartkowiak-Broda, I., Piotrowska, A., Hernacki, B., Michalski, K. \& Krotka, K. 2011. Genetic and molecular analysis of specific-origin yellow-seeded winter rapeseed (B. napus L. var. oleifera). In: Proceedings of 13th International Rapeseed Congress, 5-9 June 2011. Prague, Czech Republic. http://gcirc.org/fileadmin/documents/Proceedings/IRCPrague2011vol1/genetics/Pages\%20de\%20 IRC2011-657.pdf. Accessed 1 December 2015.

Barszcz, M., Taciak, M. \& Skomial, J. 2011. A dose-response effects of tannic acid and protein on growth performance, caecal fermentation, colon morphology, and B-glicuronidase activity of rats. Journal of Animal and Feed Sciences 20: 613-625.

Boros, D., Myszka, K. \& Bartkowiak-Broda, I. 2011a. Chemical characteristics focusing on dietary fibre content and composition of meals derived from winter rapeseed differ in colour of seeds. In: Proceedings of 13th International Rapeseed Congress, $5-9$ June 2011. Prague, Czech Republic. http://gcirc.org/fileadmin/documents/Proceedings/IRCPrague2011vol2/FeedQuality/Pages\%20 de\%20IRC2011-446.pdf. Accessed 1 December 2015.

Boros, D., Ochodzki, P., Myszka, K. \& Bartkowiak-Broda, I. 2011b. Effect of long-term feeding of black and yellow types of full-fat rapeseed on growth and reproduction of rats. In: Proceedings of 13th International Rapeseed Congress, 5 - 9 June 2011. Prague, Czech Republic. http://gcirc.org/fileadmin/documents/Proceedings/IRCPrague2011vol2/FeedQuality/Pages\%20de\%20IRC2011411.pdf. Accessed 1 December 2015.

Buraczewska, L. 2001. Fibre components negatively affect ileal protein digestibility in pigs. Journal of Animal and Feed Sciences 10: 139-152.

Campbell, L.D. \& Schöne, F. 1998. Effects of antinutritional factors in rapeseed. In: Jansman A.J.M., Hill G.D., Huisman J., van der Poel A.F.B. (eds). Recent advances of research in antinutritional factors in legume seeds and rapeseed. Wageningen Pers, The Netherlands. p. 185-198.

Czerwinski, J., Smulikowska, S., Mieczkowska, A., Konieczka, P., Piotrowska, A. \& Bartkowiak-Broda, I. 2012. The nutritive value and phosphorus availability of yellow- and dark-seeded rapeseed cakes and the effects of phytase supplementation in broilers. Journal of Animal and Feed Sciences 21: 677-695.

GfE 2008. Recommendation for the supply of energy and nutrients to pigs. DLG-Verlags-GmbH, Frankfurt am Main, Germany. 245 p.

ISO 1992. Rapeseeds - Determination of glucosinolates content. Part 1. Method using gradient elution high performance liquid chromatography. ISO 9167-1. Geneva.

ISO 2003. Animal feed stuffs, animal products, and feaces or urine. Determination of gross calorific value. Bomb calorimeter method. ISO 9831. Geneva.

Jansman, A.J.M., Smink, W., van Leeuwen, P. \& Rademacher, M. 2002. Evaluation through literature data of the amount and amino acid composition of basal endogenous crude protein at the terminal ileum of pigs. Animal Feed Science and Technology 98: 49-60.

Khajali, F. \& Slominski, B.A. 2012. Factors that affect the nutritional value of canola meal for poultry. Poultry Science 91: 2564-2575.

Kimura, F.T. \& Miller, V.L. 1957. Improved determination of chromic oxide in cow feed and feces. Journal of Agriculture and Food Chemistry 5: 216.

Mejicanos, G., Sanjayan, N., Kim, I.H. \& Nyachoti, C.M. 2016. Recent advances in canola meal utilization in swine nutrition. Journal of Animal Science and Technology 58: 1-13.

NRC 1998. Nutrient requirements of swine. 10th ed. National Academy Press. Washington, DC. 189 p.

NRC 2012. Nutrient requirements of swine. 11th ed. National Academies Press. Washington, DC. 400 p.

Nyström, R., Pastuszewska, B., Buraczewska, L., Tulisalo, U. \& Ochtabinska, A. 1996. Effects of pressing technology of oil separation and heat treatment on the protein value of low-glucosinolate rapeseed cake for non-ruminants. Journal of Animal and Feed Sciences 5: 235-248.

Rahman, M. \& McVetty, P.B.E. 2011. A review of Brassica seed color. Canadian Journal of Plant Science 91: 437-446.

Rubio, L.A., Grant, G., Daguid, T., Brown, D. \& Pusztai, A. 1999. Organs relative weight and plasma amino acid concentrations in rats fed diets based on whole legume (faba beans, lupin, chickpea, defatted soybean) seed meals or their fractions. Journal of the Science of Food and Agriculture 79: 187-194.

Sauvant, D., Perez, J.-M. \& Tran, G. 2004. Tables of composition and nutritional values of feed materials: pigs, poultry, cattle, sheep, goats, rabbits, horses and fish. In: Sauvant, D., Perez, J.-M. \& Tran, G. (eds). 2nd ed. INRA. Wageningen Academic Publishers. 304 p.

Schöne, F., Graf, T. \& Weber, M. 2011. Rapeseed press cake - Composition and results in pig testing. In: Proceedings of 13th International Rapeseed Congress, 5 - 9 June 2011. Prague, Czech Republic. http://gcirc.org/fileadmin/documents/Proceedings/ IRCPrague2011vol2/ FeedQuality/Pages\%20de\%20IRC2011-478.pdf. Accessed 1 December 2015. 
Simbaya, J., Slominski, B.A., Rakow, G., Campbell, L.D., Dowley, R.K. \& Bell, J.M. 1995. Quality characteristics of yellow-seeded Brassica seed meals. Protein, carbohydrates, and dietary fibre components. Journal of Agriculture and Food Chemistry 43: 2062-2066.

Slominski, B.A., Jia, W., Mikulski, D., Rogiewicz, A., Jankowski, J., Rakow, G., Jones, R.O. \& Hickling, D. 2011. Chemical composition and nutritive value of low-fiber yellow-seeded B. napus and $B$. juncea canola for poultry. In: Proceedings of 13th International Rapeseed Congress, 5-9 June 2011. Prague, Czech Republic. http://gcirc.org/fileadmin/documents/ Proceedings/IRCPrague2011vol2/FeedQuality/Pages\%20de\%20IRC2011-443.pdf. Accessed 1 December 2015.

Slominski, B.A., Jia, W., Mikulski, D., Rogiewicz, A., Nyachoti, C.M. \& Hickling, D. 2012. Low-fiber canola. Part 1. Chemical and nutritive composition of the meal. Journal of Agriculture and Food Chemistry 60: 12225-12230.

Slominski, B.A., Simbaya, J., Campbell, L.D., Rakow, G. \& Guenter, W. 1999. Nutritive value for broilers of meals derived from newly developed varieties of yellow-seeded canola. Animal Feed Science and Technology 78: 249-262.

Smulikowska, S., Pastuszewska, B., Ochtabinska, A. \& Mieczkowska, A. 1998. Composition and nutritional value for chickens and rats of seeds, cakes and solvent meals from low-glucosinolate yellow-seeded spring rape and dark-seeded winter rape. Journal of Animal and Feed Sciences 7: 415-428.

StatSoft 2011. STATISTICA (data analysis software system) version 10. http://www.statsoft.com.

Tripathi, M.K. \& Mishra, A.S. 2007. Glucosinolates in animal nutrition: A review. Animal Feed Science and Technology 132: 1-27.

van Leeuwen, P., van Kleef, D., van Kempen, G.J.M., Huisman, J. \& Verstegen, M.W.A. 1991. The post valve T-caecum cannulation technique in pigs applicated to determine the digestibility of amino acid in maize, groundnut and sunflower meal. Journal of Animal Physiology and Animal Nutrition 65: 183-193.

van Soest, P.J. \& Wine, R.H. 1967. Use of detergents in the analysis of fibrous feeds. IV. Determination of plant cell constituents. Journal of the Association of Official Analytical Chemists 50: 50-55.

van Soest, P.J. 1973. Collaborative study of acidic detergent fiber and lignin. Journal of the Association of Official Analytical Chemists 56: 781-784.

Zdunczyk, Z., Mikulski, D., Juskiewicz, J., Jankowski, J. \& Słonimski, B. 2011. Gastrointestinal tract response of young turkeys fed meals derived from low-fibre yellow-seeded $B$. napus and B. juncea canola. In: Proceedings of 13th International Rapeseed Congress, 5-9 June 2011. Prague, Czech Republic. http://gcirc.org/fileadmin/documents/Proceedings/IRCPrague2011 vol2/FeedQuality/Pages\%20de\%20IRC2011-430.pdf. Accessed 1 December 2015. 